\title{
Ipsilateral testicular necrosis and atrophy after 1,080-degree torsion of the spermatic cord in rats $^{1}$
}

\author{
Necrose e atrofia do testículo ipsilateral após torção de 1080 graus do cordão espermático em \\ ratos
}

\author{
Frederico Ramalho Romero ${ }^{I}$, Regina Paula Xavier Gomes ${ }^{I I}$, Fernando Lorenzini' ${ }^{I I I}$, Thomas Rolf Erdmann ${ }^{\mathrm{IV}}$, Renato Tambara \\ Filhov
}

${ }^{\mathrm{I}} \mathrm{MD}$, Master in Surgery, UFPR, Curitiba-PR, Brazil.

${ }^{\text {II }} \mathrm{PhD}$, Division of Urology, Department of Surgery, UFPR, Curitiba-PR, Brazil.

III MD, Associate Professor, Division of Urology, Department of Surgery, UFPR, Curitiba-PR, Brazil.

IV Graduate Student, School of Medicine, UFPR, Curitiba-PR, Brazil.

${ }^{v}$ Full Professor, Division of Urology, Department of Surgery, UFPR, Curitiba-PR, Brazil.

\begin{abstract}
Purpose: To assess the incidence of testicular necrosis/atrophy immediately after 1 to 4 hours of 1,080-degree torsion of the spermatic cord, and 60 days after detorsion of the spermatic cord. Methods: 42 rats were divided in 7 groups. Except for the control group, surgical torsion of the right spermatic cord was performed in all groups (T0). After 1, 2, or 4 hours of torsion, each group underwent either ipsilateral orchiectomy (groups OT1, OT2, and OT4), or detorsion of the spermatic cord and observation for 60 days (groups DT1, DT2, and DT4), before they were evaluated for the presence of testicular necrosis/atrophy. Results: Only one rat (5.5\%) in groups OT1, OT2, and OT4 had testicular necrosis, in comparison with six rats (33.3\%) in groups DT1, DT2, and DT4 ( $\mathrm{p}=0.04)$. The incidence of testicular necrosis/atrophy was not different between subgroups T1, T2, and T4, and the control group (p>0.05). There was, however, a tendency toward greater incidence of necrosis/atrophy in the rats in group DT4. Conclusion: The incidence of testicular necrosis/atrophy immediately after 1 to 4 hours of 1,080-degree torsion of the spermatic cord is 5.5\%, in comparison with $33.3 \%$ sixty days after detorsion of the spermatic cord.
\end{abstract}

Key words: Spermatic Cord Torsion. Necrosis. Urologic Surgical Procedures. Rats.

\section{RESUMO}

Objetivo: Avaliar a incidência de necrose/atrofia testicular imediatamente após 1 a 4 horas de torção de 1080 graus do cordão espermático e 60 dias após a destorção do cordão espermático. Métodos: 42 ratos foram separados em 7 grupos. Exceto para o grupo controle, todos os animais foram submetidos à torção operatória do cordão espermático direito (T0). Após 1, 2 ou 4 horas de torção, cada grupo foi submetido a orquiectomia ipsilateral (grupos OT1, OT2 e OT4), ou destorção do cordão espermático e observação por 60 dias (grupos DT1, DT2 e DT4), antes de serem avaliados para a presença de necrose/atrofia testicular. Resultados: Somente um rato (5,5\%) nos grupos OT1, OT2 e OT4 apresentou necrose testicular em comparação com 6 ratos (33,3\%) nos grupos DT1, DT2 e DT4 (p=0,04). A incidência de necrose/atrofia testicular não foi diferente entre os subgrupos T1, T2 e T4 e o grupo controle ( $p>0,05$ ). Houve, no entanto, uma tendência a maior incidência de necrose/atrofia nos ratos do grupo DT4. Conclusão: A incidência de necrose/atrofia testicular imediatamente após 1 a 4 horas de torção de 1080 graus do cordão espermático é de 5,5\% em comparação com 33,3\% sessenta dias após a destorção do cordão espermático.

Descritores: Torção do Cordão Espermático. Necrose. Procedimentos Cirúrgicos Urológicos. Ratos.

${ }^{1}$ Research performed at Department of Surgery, Federal University of Parana (UFPR), Curitiba-PR, Brazil.

\section{Introduction}

Torsion of the spermatic cord (testicular torsion) is an emergency that results from rotation of the testis and epididymis around the axis of the spermatic cord. The annual incidence of testicular torsion is between one in 4,000 males and one in 158 males younger than 25 years, with peaks of incidence occurring in neonates and adolescents entering puberty. ${ }^{1,2}$ Immediate diagnosis 
and prompt surgical treatment are important to avoid permanent damage to the testis. Misdiagnosis or delay in diagnosis frequently result in loss of the ipsilateral testis, which may cause decreased spermatogenesis in $50 \%$ to $95 \%$ of patients, reducing fertility rates with potential medicolegal implications. ${ }^{3}$ Further, testicular atrophy following torsion of the spermatic cord has been reported to increase the risk of testicular cancer. ${ }^{4}$

Experimental models of testicular torsion are valuable tools to evaluate the relationship between the degree and duration of torsion with the blood flow and resultant damage to the torsed testes. The results, however, have been conflicting. With 720-degree of torsion, several studies have reported reduction in testicular blood flow varying from $61.7 \%$ to $100 \% ;^{5-8}$ with ischemic injury after periods of time as diverse as 1 hour and 8 hours of torsion. ${ }^{7-11}$

This experimental study with rats was performed with the objective of assessing the incidence of testicular necrosis immediately after one to four hours of 1,080-degree torsion of spermatic cord (testicular ischemia); the incidence of testicular necrosis and atrophy 60 days after detorsion of the spermatic cord (testicular ischemia/reperfusion) in rats undergoing 1,080-degree torsion of the spermatic cord between one and four hours; and differences in rates of testicular necrosis immediately after 1,2 , and 4 hours of 1,080-degree torsion of spermatic cord, and 60 days following detorsion of the spermatic cord.

\section{Methods}

\section{Study design}

After approval by the Institutional Ethics in Research Committee, and following the Council for International Organization of Medical Sciences (CIOMS) ethical code for animal experimentation and the principles of the Brazilian College on Animal Experimentation, 42 male Wistar rats were randomly allocated into one of seven groups with six animals each. Except for the control group (C) that underwent sham operation, surgical torsion of the right spermatic cord was performed in the remaining six groups (T0). After different periods of torsion - 1 hour (T1), 2 hours (T2), or 4 hours (T4) - each group underwent either ipsilateral orchiectomy (groups OT1, OT2, and OT4), or detorsion of the spermatic cord (groups DT1, DT2, and DT4). The rats undergoing orchiectomy were sacrificed immediately after surgery, and the testes were evaluated morphologically, macroscopically and microscopically, for the presence of necrosis. Rats undergoing detorsion of the spermatic cord were housed in a temperature and light-dark cycle controlled environment with free access to water and rat chow. After 60 days, they underwent orchiectomy, and the testes were evaluated hystopathologically for the presence of necrosis and atrophy (Table 1).

TABLE 1 - Study design and groups of study

\begin{tabular}{|c|c|c|c|c|c|c|}
\hline \multirow{2}{*}{\multicolumn{2}{|c|}{ Groups }} & \multirow{2}{*}{$\begin{array}{c}\text { Number } \\
\text { of rats }\end{array}$} & \multirow{2}{*}{$\begin{array}{c}\text { Initial procedure } \\
\text { (T0) }\end{array}$} & \multicolumn{2}{|c|}{ Reoperation } & \multirow[b]{2}{*}{ Euthanasia } \\
\hline & & & & $\begin{array}{c}\text { Time from } \\
\text { T0 }\end{array}$ & Surgery & \\
\hline \multirow{2}{*}{\multicolumn{2}{|c|}{$\mathbf{C}$}} & 3 & \multirow[b]{2}{*}{ Sham operation } & $\begin{array}{c}1,2 \text {, and } 4 \\
\text { hours }\end{array}$ & $\begin{array}{c}\text { Ipsilateral } \\
\text { orchiectomy }\end{array}$ & $\begin{array}{c}\text { Immediately after } \\
\text { surgery }\end{array}$ \\
\hline & & 3 & & $\begin{array}{l}1,2 \text {, and } 4 \\
\text { hours }\end{array}$ & $\begin{array}{c}\text { Second sham } \\
\text { operation }\end{array}$ & After 60 days \\
\hline \multirow[t]{3}{*}{$\mathbf{O}$} & T1 & 6 & \multirow{6}{*}{$\begin{array}{l}\text { Torsion of the right } \\
\text { spermatic cord }\end{array}$} & 1 hour & \multirow{3}{*}{$\begin{array}{l}\text { Ipsilateral } \\
\text { orchiectomy }\end{array}$} & \multirow{3}{*}{$\begin{array}{c}\text { Immediately after } \\
\text { surgery }\end{array}$} \\
\hline & $\mathbf{T} 2$ & 6 & & 2 hours & & \\
\hline & T4 & 6 & & 4 hours & & \\
\hline \multirow[t]{3}{*}{ D } & T1 & 6 & & 1 hour & \multirow{3}{*}{$\begin{array}{l}\text { Detorsion of } \\
\text { the spermatic } \\
\text { cord }\end{array}$} & \multirow{3}{*}{ After 60 days } \\
\hline & $\mathbf{T} 2$ & 6 & & 2 hours & & \\
\hline & T4 & 6 & & 4 hours & & \\
\hline
\end{tabular}

NOTES : $\mathrm{O}=$ Group of rats undergoing ipsilateral orchiectomy

$\mathrm{D}=$ Group of rats undergoing detorsion of the spermatic cord

$\mathrm{T} 0=$ Initial procedure (torsion of the right spermatic cord) performed in groups $\mathrm{O}$ and $\mathrm{D}$

$\mathrm{T} 1=$ Subgroup of rats undergoing surgery 1 hour after initial procedure

$\mathrm{T} 2=$ Subgroup of rats undergoing surgery 2 hours after initial procedure

$\mathrm{T} 4=$ Subgroup of rats undergoing surgery 4 hours after initial procedure 


\section{Torsion of the right spermatic cord}

Expect for the control group, all rats underwent torsion of the right spermatic cord at T0. After intraperitoneal anesthesia using ketamine $(50 \mathrm{mg} / \mathrm{kg})$ and xylazine $(10 \mathrm{mg} / \mathrm{kg})$, a midline scrotal incision was made. The right testis was delivered and, after division of the gubernaculum, it was rotated three times $(1,080 \mathrm{de}-$ grees) along the longitudinal axis of the spermatic pedicle in a clockwise fashion, and fixed within the scrotum with 7-0 braided polyester sutures. Scrotal skin was closed with 4-0 plain catgut sutures.

\section{Detorsion of the spermatic cord}

Groups DT1, DT2, and DT4 underwent detorsion of the spermatic cord after the following periods of testicular torsion: 1 hour, 2 hours, and 4 hours, respectively. Intraperitoneal anesthesia was performed with ketamin and xylazine, and the previously positioned suture line in the scrotum was incised. The sutures fixing the testis within the scrotum were identified and cut. The torsion was relieved by rotating the testis three times (1,080 degrees) in a counter-clockwise fashion, which was then fixed in position with 7-0 braided polyester sutures.

\section{Sham operation}

All 6 rats in the control group underwent a sham operation similar to that reported above (torsion of the right spermatic cord). Intraperitoneal anesthesia, median scrotal incision, delivery of the right testis, and fixation of the testis within the scrotum were performed, without twisting the testicle. Three rats in the control group were also submitted to a second sham operation following the same steps of detorsion of the spermatic cord, with intraperitoneal anesthesia, incision of the scrotal skin sutures and fixation sutures within the scrotum, and refixation of the testis without detorsion of the spermatic cord.

\section{Orchiectomy}

Removal of the testes for hystopathological evaluation was performed immediately after 1, 2, and 4 hours in groups OT1, OT2, and OT4, respectively, and after 60 days in groups DT1, DT2, and DT4. After intraperitoneal anesthesia, the scrotum was entered; sutures fixing the testis were incised; the spermatic cord was clamped with hemostatic forceps, transected, and ligated with 2-0 silk sutures; and the removed testis was incised and fixed in Bouin's solution.

In the control group, three rats underwent orchiectomy 1, 2 , and 4 hours immediately after the first sham operation, respectively; and three rats underwent orchiectomy 60 days after the second sham operation.

\section{Euthanasia}

Immediately after orchiectomy for groups OT1, OT2, and OT4, and after 60 days for groups DT1, DT2, and DT4, the rats were sacrificed with intoxication by sulfuric ether in a closed recipient.

\section{Pathologic evaluation}

All specimens were fixed in Bouin's solution, embedded in paraffin wax, sectioned with $3 \mu \mathrm{m}$ thickness, stained with haematoxylin and eosin (H\&E), and examined blindly by the same pathologist. Samples were examined under different levels of magnification, ranging from 40 to 600 times, in a total of 10 highpower fields. Testicular hemorrhagic necrosis, with or without associated testicular atrophy, was investigated. Lesions were considered to be present if they were seen in the majority (more than $50 \%$ ) of the examined tubules.

\section{Statistical analysis}

The results were considered categorical variables (presence or absence of testicular necrosis and atrophy). Comparison between groups was performed by Fisher's exact test, with the help of SPSS for Windows, versions 13.0. P values $<0.05$ were considered to be significant.

\section{Results}

\section{Testicular ischemia}

In groups OT1, OT2, and OT4, which underwent ipsilateral orchiectomy immediately after 1, 2, and 4 hours of 1,080degree torsion of the spermatic cord, respectively, testicular necrosis was not detected macroscopically in any of the rats (Figure 1), and only one $(5.5 \%)$ rat presented testicular necrosis histologically (Figure 2, Table 2-A).

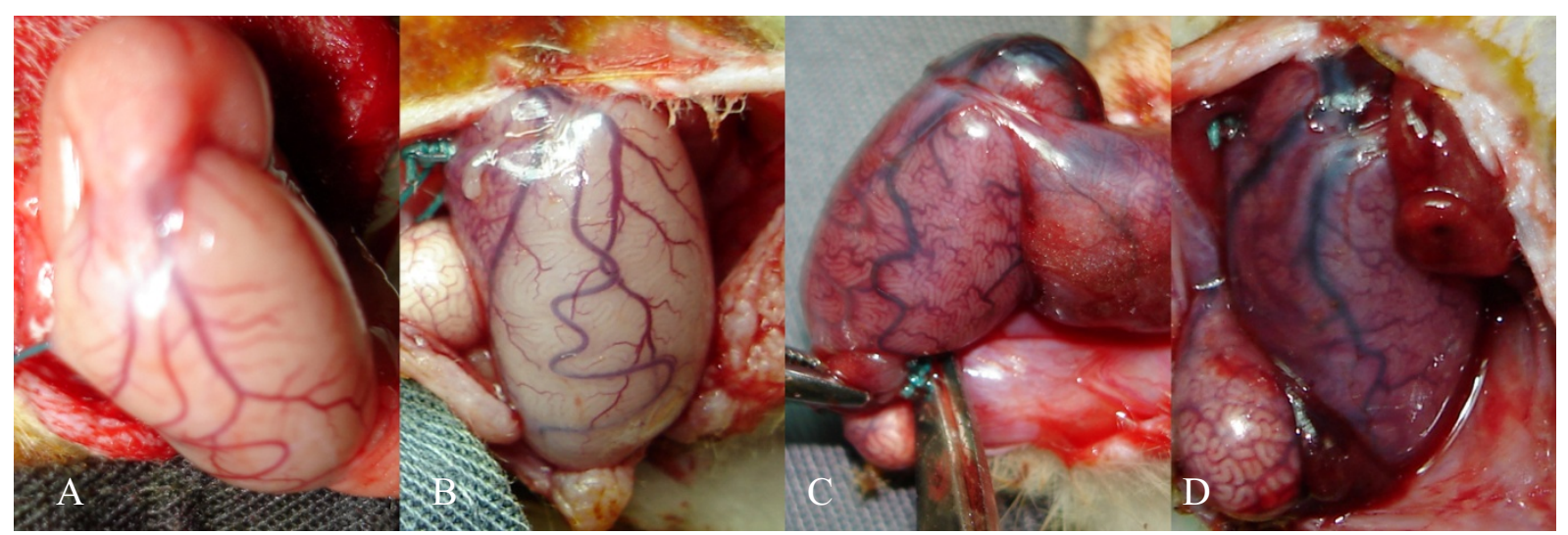

FIGURE 1 - Macroscopic appearance of the testis in the control group (A), and after 1 hour (B), 2 hours (C), and 4 hours of 1,080-degree torsion (D) 


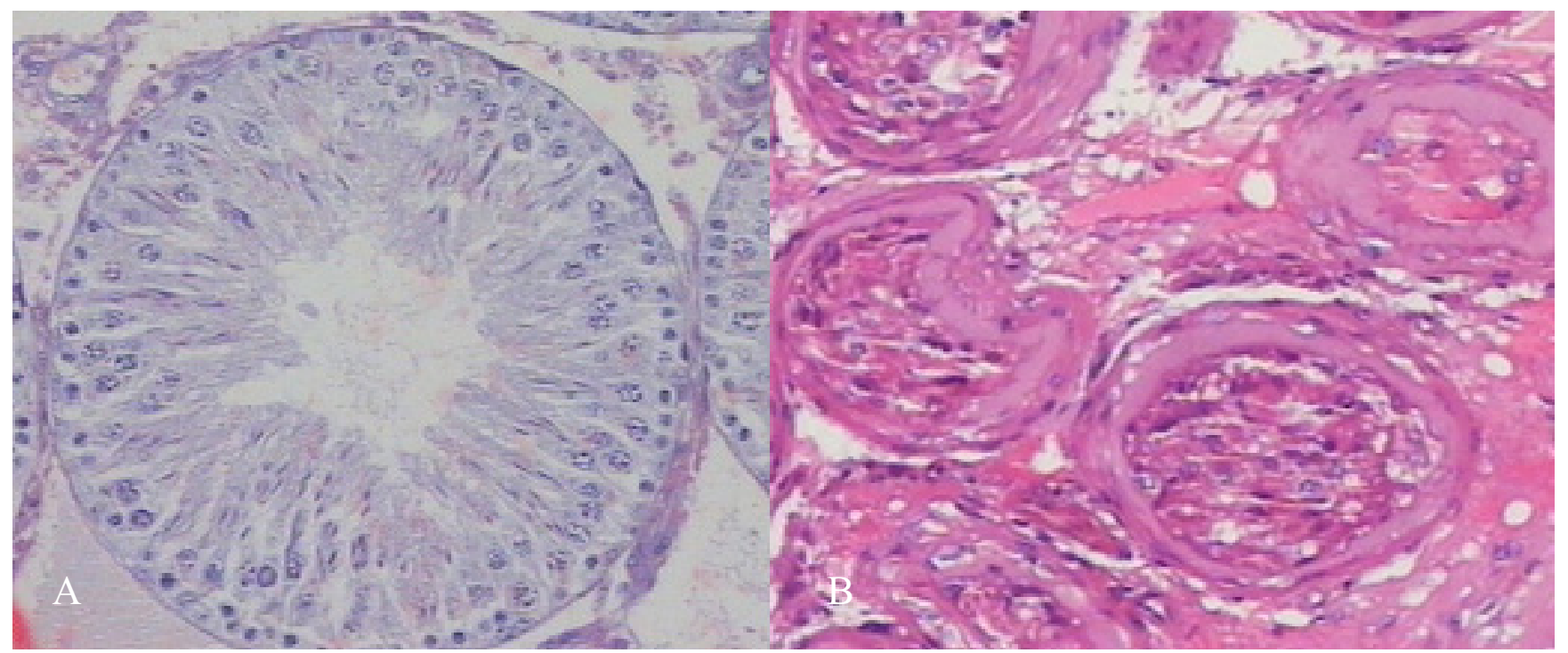

FIGURE 2 - Histologic appearance of the testes. A. Normal seminiferous tubule (H\&E, X400). B. Necrotic tubules, with marked reduction in spermatogenesis, containing rare spermatogonia or only Sertoly cells, and thickening of the basement membrane (H\&E, X170)

\section{Testicular ischemia/reperfusion}

Six rats $(33.3 \%)$ in groups DT1, DT2, and DT4, which underwent spermatic cord detorsion after 1, 2, and 4 hours of 1,080-degree torsion and histological evaluation after 60 days, developed testicular necrosis and atrophy (Figure 3 ). The incidence of testicular necrosis in groups DT1, DT2, and DT4 was higher than in groups OT1, OT2, and OT4 $(p=0.04)$. The incidence of testicular necrosis/atrophy was not different between groups DT1, DT2, and DT4, and the control group, although there was a tendency toward higher incidence of testicular necrosis/atrophy in group DT4 (Table 2-B).

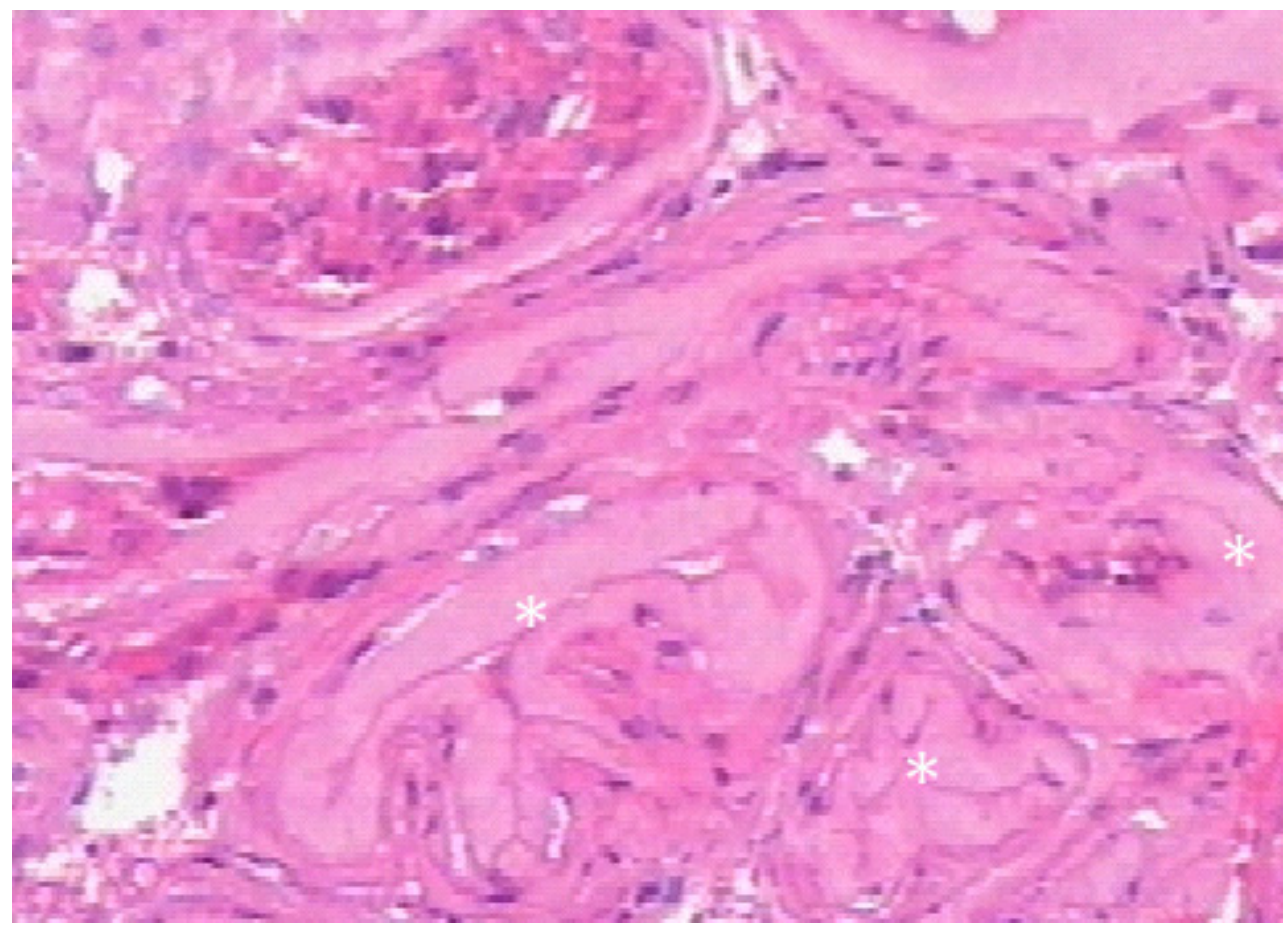

FIGURE 3 - Testis containing tubular atrophy $(*)$ with complete absence of spermatogenic cells and marked thickening of the basement membrane (H\&E, X170) 
TABLE 2 - A. Presence of ipsilateral testicular necrosis in the groups of rats undergoing orchiectomy in comparison with control group; B. Presence of ipsilateral testicular necrosis/atrophy in the groups of rats undergoing detorsion of the spermatic cord in comparison with control group

\begin{tabular}{|c|c|c|c|c|c|c|c|c|c|}
\hline \multirow{3}{*}{$\begin{array}{l}\text { A } \\
\text { Groups } \\
\end{array}$} & \multicolumn{4}{|c|}{ Testicular necrosis } & \multirow{3}{*}{ p value } & \multirow{3}{*}{$\begin{array}{l}\text { B } \\
\text { Groups }\end{array}$} & \multirow{2}{*}{\multicolumn{2}{|c|}{ Necrosis/atrophy }} & \multirow{3}{*}{ p value } \\
\hline & \multicolumn{2}{|c|}{ Macroscopic } & \multicolumn{2}{|c|}{ Histological } & & & & & \\
\hline & $\begin{array}{c}\text { No } \\
\mathrm{N}(\%) \\
\end{array}$ & $\begin{array}{c}\text { Yes } \\
\mathrm{N}(\%) \\
\end{array}$ & $\begin{array}{c}\text { No } \\
\mathrm{N}(\%) \\
\end{array}$ & $\begin{array}{c}\text { Yes } \\
\mathrm{N}(\%) \\
\end{array}$ & & & $\begin{array}{c}\text { No } \\
\mathrm{N}(\%) \\
\end{array}$ & $\begin{array}{c}\text { Yes } \\
\mathrm{N}(\%)\end{array}$ & \\
\hline OT1 & $6(100)$ & $0(0)$ & $6(100)$ & $0(0)$ & $>0,05$ & DT1 & $5(83,3)$ & $1(16,7)$ & $>0,05$ \\
\hline OT2 & $6(100)$ & $0(0)$ & $6(100)$ & $0(0)$ & $>0,05$ & DT2 & $4(66,7)$ & $2(33,3)$ & $>0,05$ \\
\hline OT4 & $6(100)$ & $0(0)$ & $5(83,3)$ & $1(16,7)$ & $>0,05$ & DT4 & $3(50,0)$ & $3(50,0)$ & $>0,05$ \\
\hline $\mathbf{C}$ & $6(100)$ & $0(0)$ & $6(100)$ & $0(0)$ & - & $\mathrm{C}$ & $6(100)$ & $0(0)$ & - \\
\hline
\end{tabular}

NOTES : $\mathrm{N}(\%)=$ Number of rats (percentage)

$\mathrm{O}=$ Group of rats undergoing ipsilateral orchiectomy

$\mathrm{D}=$ Group of rats undergoing detorsion of the spermatic cord

$\mathrm{C}=$ Control group

$\mathrm{T} 1=$ Subgroup of rats undergoing surgery 1 hour after initial procedure

$\mathrm{T} 2=$ Subgroup of rats undergoing surgery 2 hours after initial procedure

$\mathrm{T} 4=$ Subgroup of rats undergoing surgery 4 hours after initial procedure

\section{Discussion}

Experimental spermatic cord torsion has been widely studied under several different aspects, including the effect of ischemia on testicular structure, ischemia/reperfusion, contralateral testis injury, and measures to avoid or reduce these injuries. Studies in the literature have used different methodology, however, with conflicting results. Factors such as animal type and species, age, model of ischemic injury, ischemia time, and technique for the evaluation of testicular injury make the analysis and comparison between studies difficult. ${ }^{12}$

Animal models are important in the investigation of spermatic cord torsion because of the complexity and relative rarity of this emergency in humans. ${ }^{1,2}$ These models allow us to evaluate the relationship between occlusion of the spermatic cord, persistent blood flow, and the resulting testicular injuries. ${ }^{6}$ The rat is the most widely used animal in the spermatic cord torsion model. Rats are cheaper and have a similar testicular volume to that of larger animal models. Normal spermatogenesis is expected to occur in rats older than 45 days. ${ }^{6,13}$ There are age-dependent modifications in hormonal, metabolic, and vasomotor activity that may be responsible for the conflicting results reported in the literature.${ }^{14}$ For these reasons, all animals used in our study were aged between 70 and 90 days old.

Two models of spermatic cord occlusion have traditionally been used, including the 720-degree torsion and cross clamping, or ligature, of the spermatic cord. Torsion, however, differs from clamping or ligature because it occludes initially the testicular veins, but not the arteries of the spermatic cord. ${ }^{13}$ Additionally, while seminiferous tubule degeneration is always present in the clamped group, it occurs in only $67 \%$ of the 720 -degree group. ${ }^{5}$

Several experimental studies reported that 720 -degree torsion severely restricts testicular blood flow. There is variation both within and between species in the absolute amount of persistent blood flow to the testis. ${ }^{8}$ While some authors have reported decreases in blood flow to below $10 \%$ of control values, ${ }^{6-8}$ others have reported less important reductions, ranging from $16 \%$ to $38.3 \%,{ }^{5,15}$ suggesting the 720 -degree model is not as stringent a model of testicular ischemia as cord clamping. ${ }^{5}$ We developed a new spermatic cord torsion model of 1,080-degree torsion in an attempt to reduce the conflicting results reported in the literature.

Most studies evaluating the critical time to detect testicular injury after a 720-degree torsion model agree that ipsilateral ischemic lesions can be found after one to four hours of torsion. Therefore, we performed a 1,080-degree torsion of the spermatic cord for 1, 2, and 4 hours to evaluate the presence of testicular necrosis and atrophy. In clinical practice, necrotic testes are usually removed to avoid contralateral testicular injury potentially reducing fertility rates, and the risk of atrophy-related testicular cancer. $^{4}$

Our results showed that the ischemic injury produced by 1,080-degree torsion of the spermatic cord did not result in significant macroscopic or histological testicular necrosis after 1 to 4 hours of torsion, suggesting there may be persistent blood flow to the testis and testicular viability even with this degree of testicular torsion. In humans, these testes would be considered for preservation through operative detorsion and orchidopexy. Sixty days after reperfusion, however, testicular necrosis/atrophy developed in $33.3 \%$ of rats. The incidence of testicular necrosis/atrophy increased in parallel to the increasing time of torsion. Animals undergoing 1, 2, or 4 hours of torsion (DT1, DT2, and DT4) had, respectively, $16.7 \%, 33.3 \%$, and $50 \%$ of testicular necrosis/atrophy, but these differences did not reach statistical significance. Although rats undergoing detorsion after 4 hours of 1,080-degree torsion had a tendency toward higher incidence of testicular necrosis/atrophy, the presence of necrosis/atrophy in all groups of rats after 60 days of detorsion suggest potential irreversible testicular injury even in the 1, and 2-hour torsion groups. In these groups, occurrence of necrosis/atrophy after 60 days of detorsion indicate progression of ischemic injury that was not detected by the morphologic technique used in the present study, or development of new lesions by the ischemia/reperfusion effect. Although necrosis 
and atrophy are the known end-result of ischemia-related injury, they are late and irreversible indicators of testicular injury. Future studies with a larger sample, and more sensitive techniques to detect testicular injury are necessary to determine the critical time beyond which testicular lesions become irreversible after 1,080-degree torsion of the spermatic cord.

Based on the new spermatic cord torsion model presented in this manuscript, other investigations can be performed, including assessment of the degree of vascular insufficiency with a 1,080degree torsion; comparison of 1,080-degree torsion with 720degree torsion, or clamping/ligature of the spermatic cord; determination of the point of reperfusion failure, which is the point beyond which there is ischemia without effective reperfusion; the use of pharmacologic agents to reduce the effects of oxidative stress (isquemia/reperfusion injury); and the effects of torsion on the contralateral testis.

\section{Conclusions}

Testicular ischemia resulting from 1,080-degree torsion of the spermatic cord cause testicular necrosis in only $5.5 \%$ of testes evaluated histologically immediately after 1 to 4 hours of torsion. The rate of testicular necrosis is higher 60 days after detorsion with 1 to 4 hours of spermatic cord torsion, than immediately after 1,080-degree torsion of the spermatic cord, with an incidence of $33.3 \%$. Although animals undergoing 1, 2, or 4 hours of torsion have similar rates of testicular necrosis after 60 days of detorsion, there is a tendency toward higher incidence of testicular necrosis/ atrophy after 4 hours of 1,080-degree torsion.

\section{References}

1. Williamson RC. Torsion of the testis and allied conditions. Br J Surg. 1976;63(6):465-76.
2. Anderson JB, Williamson RC. The fate of the human testes following unilateral torsion of the spermatic cord. Br J Urol. 1986;58(6):698-704. 3. Perotti M, Badger W, Prader S, Moran ME. Medical malpractice in urology, 1985 to 2004: 469 consecutive cases closed with indemnity payment. J Urol. 2006;176(5):2154-7.

4. Chilvers CE, Pike MC, Peckham MJ. Torsion of the testis: a new risk factor for testicular cancer. Br J Cancer. 1987;55(1):105-6.

5. Palmer JS, Plzak LF, Cromie WJ. Comparison of blood flow and histological changes in rat models of testicular ischemia. J Urol. 1997;158(3):1138-40.

6. Becker EJ, Prillaman HM, Turner TT. Microvascular blood flow is altered after repair of testicular torsion in the rat. J Urol. 1997;157(4):1493-8.

7. Turner TT. Acute experimental testicular torsion. No effect on the contralateral testis. J Androl. 1985;6(1):65-72.

8. Turner TT, Brown KJ. Spermatic cord torsion: loss of spermatogenesis despite return of blood flow. Biol Reprod. 1993;49(2):401-7.

9. Nguyen L, Lievano G, Ghosh L, Radhakrishnan J, Fornell L, John E. Effect of unilateral testicular torsion on blood flow and histology of contralateral testes. J Pediatr Surg. 1999;34(5):680-3.

10. Gezici A, Ozturk H, Buyukbayram H, Ozturk H, Okur H. Effects of gabexate mesilate on ischemia-reperfusion-induced testicular injury in rats. Pediatr Surg Int. 2006;22(5):435-41.

11. Beheshtian A, Salmasi AH, Payabvash S, Kiumehr S, Ghazinezami B, Rahimpour S, Tavangar SM, Dehpour AR. Protective effects of sildenafil administration on testicular torsion/detorsion damage in rats. World J Urol. 2008;26(2):197-202.

12. Silva AC, Ortiz V, Silva RA, Tognini JR. Effect of allopurinol on rat testicles morphology, submitted to ischaemia for spermatic cord torsion followed by reperfusion. Acta Cir Bras. 2005;20(6):468-72.

13. Consentino MJ, Nishida M, Rabinowitz R, Cockett AT. Histopathology of prepubertal rat testes subjected to various durations of spermatic cord torsion. J Androl. 1986;7(1):23-31.

14. Damber JE, Bergh A, Widmark A. Age related differences in testicular microcirculation. Int J Androl. 1990;13(3):197-206.

15. Unluer SE, Ercan MT, Akdas A. Testicular blood flow in experimental torsion and epididymo-orchitis measured by $133 \mathrm{Xe}$ clearance technique in rabbits. Urol Res. 1984;12(3):183-6.

Conflict of interest: none Financial source: none

\section{Correspondence:}

Frederico Ramalho Romero

Rua Emiliano Perneta, 653/41

80420-080 Curitiba - PR Brazil

Phone: (55 41)3324-9088 / 8441-0377

frederico.romero@gmail.com

\section{How to cite this article}

Romero FR, Gomes RPX, Lorenzini F, Erdmann TR, Tambara Filho R. Ipsilateral testicular necrosis and atrophy after 1,080-degree torsion of the spermatic cord in rats. Acta Cir Bras. [serial on the Internet] 2009 Mar-Apr;24(2). Available from URL: http://www.scielo.br/acb

*Color figures available from www.scielo.br/acb 